\title{
Correction to: Major in Vitro Techniques for Potato Virus Elimination and Post Eradication Detection Methods. A Review
}

\author{
Huiling Gong ${ }^{1} \cdot$ Clement Igiraneza $^{1} \cdot$ Leonce Dusengemungu ${ }^{1}$
}

Published online: 5 August 2019

(C) The Potato Association of America 2019

\section{Correction to: American Journal of Potato Research} https://doi.org/10.1007/s12230-019-09720-z

The following two references should be deleted:

Nie, X., and M. Singh. 2008. Plant virology protocols. Methods in Molecular Biology 451: 1-289.

Nie X, Singh M, 2015. Plant virology protocols. New approaches to detect viruses and host responses. 3rd ed.

They are replaced by the following reference:

MacKenzie TDB, Nie X, and Singh M. 2015. RT-PCR and Real-Time RT-PCR methods for the detection of Potato virus $\mathrm{Y}$ in potato leaves and tubers. Plant Virology Protocols Methods in Molecular Biology 1236: 13-26 https://doi.org/ 10.1007/978-1-4939-1743-3 2

Publisher's Note Springer Nature remains neutral with regard to jurisdictional claims in published maps and institutional affiliations.

The online version of the original article can be found at https://oi.org/ 10.1007/s12230-019-09720-Z

Huiling Gong gonghl@lut.cn

1 School of Life Sciences and Engineering, Lanzhou University of Technology, 287 Langongping Road, Lanzhou City, Gansu Province 730050, People's Republic of China 